\section{Lugares (em tensão) no jogo argumentativo: garota de programa e maternidade*}

Locations (in tension) in the argumentative game: prostitution and maternity

Mirielly FERRAÇA (Unicamp) miriellyferraca@gmail.com

Recebido em: 27 de ago. de 2018. Aceito em: 12 de jan. de 2019.

O presente trabalho foi realizado com apoio da Coordenação de Aperfeiçoamento de Pessoal de Nível Superior - Brasil (CAPES) - Código de Financiamento 001.
FERRAÇA, Mirielly. Lugares (em tensão) no jogo argumentativo: garota de programa e maternidade. Entrepalavras, Fortaleza, v. 9, n. 1, p. 252-269, jan-abr/2018

Resumo: A partir de entrevistas realizadas com prostitutas em uma casa noturna localizada na cidade de CascavelPR, com aprovação e consentimento do Comitê de Ética em Pesquisa da Universidade Estadual do Oeste do Paraná (Unioeste), este artigo pretende dar visibilidade ao direcionamento argumentativo movimentado na cena do acontecimento enunciativo. Como aporte teórico, este trabalho se inscreve na Semântica do Acontecimento, teoria de base materialista, desenvolvida por Eduardo Guimarães (2005, 2009, 2010, 2013a, 2013b). Pretende-se a) identificar a cena enunciativa e perceber como Locutor, Alocutário, l-x, al-x e al-y estão imbricados e como se constituem nesse espaço de enunciação; b) perceber como se dá o direcionamento argumentativo no texto; c) refletir sobre a memória que entrelaça o acontecimento, propiciando um devir.

Palavras-chave: Semântica do Acontecimento. Prostituição.
Argumentação. 
Abstract: From interviews of prostitutes from a night club located in the city of Cascavel-PR, with the approval of the State University of Western Paraná (Unioeste) Research Ethics Committee, this article intends to give visibility to the argumentative targeting moved in the scene of the enunciative event. As our theoretical basis, this work subscribes to the Semantics of the Event, a theory based on materialism developed by Eduardo Guimarães (2005, 2009, 2010, 2013a, 2013b). We intend to a) identify the enunciative scene and perceive how Sender, Receiver, $1-\mathrm{x}$, al-x and al-y are overlapped and how they constitute in this enunciative space; b) perceive how the argumentative targeting happens in the text; c) reflect on the memory that intertwines the event, propitiating a becoming.

Keywords: Semantics of the event. Argumentation. Prostitution.

\section{Introdução}

A análise empreendida neste trabalho pauta-se na Semântica do Acontecimento (GUIMARÃES, 2005, 2009, 2010, 2013a, 2013b). Nesta teoria de base materialista, a enunciação é considerada a partir da constituição histórica do sentido e do sujeito, para a qual o exterior é constitutivo da linguagem. A enunciação é, desse modo, tomada como um acontecimento no qual se encontra amarrado no espaço de enunciação a relação do sujeito com a(s) língua(s) que o constitui. Enunciar, nesse ponto de vista, passa a ser uma prática política, afetada pela história e pelo simbólico.

A partir de entrevistas realizadas com garotas de programa, em uma boate de Cascavel-PR ${ }^{1}$, pretende-se a) identificar a cena enunciativa e perceber como Locutor, Alocutário, l-x, al-x e al-y estão imbricados e como se constituem nesse espaço de enunciação; b) perceber como se dá o direcionamento argumentativo no texto; c) refletir sobre a memória que entrelaça o acontecimento, propiciando um devir.

\section{A constituição da cena enunciativa}

A Semântica do Acontecimento pauta-se numa posição materialista e considera, pois, que a linguagem não é transparente, já que sua relação com o real é histórica. Dessa forma, para a teoria, o sentido das expressões linguísticas não poderia ser apenas referencial, não se apresenta como um conceito de verdade como deseja a semântica formal (referencialista-veritativa), mas justamente o sentido significa no enunciado pela relação que estabelece com o acontecimento.

\footnotetext{
${ }^{1}$ Entrevistas aprovadas pelo Comitê de Ética em Pesquisa da Universidade Estadual do Oeste do Paraná - Unioeste, 2012. Processo: CAAEE 03230912.8.0000.0107.
} 
V. 9 (1)

252-269
Assim, quemfala (locutor) eaquelepara quem sefala(alocutário) são agenciados na cena enunciativa a partir do lugar social ocupado, e o que dizem deve ser considerado com base no funcionamento desses lugares, na relação com o político e a história inscritos na língua. Dessa forma, considerar que esse funcionamento social e político determinam os sentidos produzidos na cena enunciativa, significa de fato levar (no limite) o exterior (simbólico e ideológico) como constitutivo da enunciação, um exterior que vai além do contexto imediato de produção dos sentidos (como aquele que responderia quem, para quem, quando, onde).

O Locutor (L) é caracterizado socialmente como responsável por seus dizeres e, por estar imerso na história, que movimenta consigo o jogo político, sente o efeito de ser a origem de seu dizer. Imerso nesse esquecimento, o que é dito só pode significar no tempo presente, ou seja, o Locutor desconhece que enunciações anteriores irrompem na cena enunciativa e significam em sua própria fala. Ser a origem do dizer é metaforicamente associado por Pêcheux (2014, p. 144) ao personagem literário Barão de Münchhausen, que se ergue pelos próprios cabelos, como se estivesse na origem de si, para livrar-se da morte:

Vamos nos deter, propondo atribuir a esse efeito fantástico pelo qual o indivíduo é interpelado em sujeito - o nome de 'efeito Münchhausen', em memória do imortal barão que se levantava nos ares puxando-se pelos próprios cabelos. (grifos do autor).

O sujeito, nesse sentido, vê-se como único, insubstituível e idêntico a si, é o teatro da consciência que entra em jogo: eu vejo, eu penso, eu falo.

Tratar-se-ia de uma evidência inquestionável, assim como quando se é interrogado: "Quem és?", logo vem a óbvia resposta: "Sou eu". Pontua Althusser (apud PÊCHEUX, 2014, p. 155) que a evidência da transparência da linguagem que faz com que uma palavra designe uma coisa ou possua um significado ou ainda a evidência de nos vermos como donos de nosso discurso não são um problema, mas um efeito ideológico elementar. O problema não está nessa ilusão do domínio de si e do dizer, visto ser fundamental para o funcionamento da linguagem, mas em negar e ignorar sua existência no fazer científico.

O político em sua relação com o interdiscurso é um ponto de encontro entre Análise do Discurso e Semântica do Acontecimento, com a diferença de que para a Semântica do Acontecimento, o movimento 
político é observado no enunciado (na tomada da palavra) levando em consideração a interdiscursividade. De outro lado, para a Análise do Discurso, o político está na própria constituição interdiscursiva (o fato de que o sentido está sempre dividido, tomando uma posição que se especifica na história).

Dessa forma, enquanto teorias materialistas, tanto a Análise do Discurso como a Semântica do Acontecimento questionam, cada qual no interior de seus pressupostos teóricos, a evidência do sujeito livre, subjetivo, cartesiano. Concepção que muda, evidentemente, a lógica do que é a ciência e seus (aparentes) resultados verdadeiros e, por vezes, indiscutíveis (pretensamente absolutos):

Compreender realmente isso é o único meio de evitar repetir, sob a forma de uma análise teórica, o 'efeito Münchhausen', colocando o sujeito como origem do sujeito, isto é, no caso de que estamos tratando, colocando o sujeito do discurso como origem do sujeito do discurso. (PÊCHEUX, 2014, p. 144 - grifos nossos).

Tratar a enunciação, coloca de saída a questão do sujeito que enuncia, e assim a questão do sujeito na linguagem. E para os meus propósitos isto deve levar a uma recolocação do lugar dos estudos da enunciação num espaço distinto do que eles tiveram ou têm ainda em certas de suas formulações. Para mim o tratamento da enunciação deve se dar num espaço em que seja possível considerar a constituição histórica do sentido, de modo que a semântica se formule, claramente, como uma disciplina do campo das ciências humanas, fora de suas relações com a lógica ou com a gramática pensadas ou como o matematizável ou como uma estrutura biologicamente determinada. (GUIMARÃES, 2005, p. 8 - grifos nossos).

Pêcheux (2014) realiza fortes críticas às ciências sociais e às ciências da linguagem por se pautarem em um sujeito consciente, aquele que é capaz de convencer, persuadir, controlar os sentidos. Para o autor, deve-se compreender esse aparente domínio como um efeito evidente, uma ilusão de controle, evitando-se perpetuar o efeito Münchhausen. Teorias da enunciação como as de Jacqueline Authier-Revuz ou como as de Osvald Ducrot já trabalham esse descentramento. Entretanto, em Eduardo Guimarães a diferença está na posição materialista, que considera a cisão do sujeito (tal como a AD) e a cisão enunciativa como política (não como deontológica, tal como Ducrot, ou psíquica tal como Revuz). Interessa, portanto, não a pessoa que disse, mas a partir de qual lugar se diz. O falante, tal como conceitua Guimarães (2005, p. 18), 
V. 9 (1)

$252-269$

jan-abr

2019 é uma categoria linguística e enunciativa, [...] o falante não é esta figura empírica, mas uma figura política constituída pelos espaços de enunciação. E nesta medida ela deve ser incluída entre as figuras da enunciação.

Não o locutor de carne e osso, mas o l-x que se inscreve enunciativamente e que produz sentidos a partir dessa inscrição.

Há, portanto, uma ilusão subjetiva que constitui a relação do sujeito com a linguagem, tal como descrita por Pêcheux, pela ilusão de origem do dizer e pela ilusão referencial (efeito que produz a colagem unívoca entre signo e objeto, como se os sentidos fossem únicos). Como efeito da ilusão de origem, o locutor não percebe que é sempre agenciado em um lugar para enunciar, nem que sentidos outros, pela memória, e independente de sua vontade, irrompem em seu dizer. Mesmo que, às vezes, por outro lado, convoque certos lugares sociais explicitamente: "como deputado mais votado, agradeço...", ou produzindo um discurso populista, fale do lugar social de deputado, ou de qualquer outro lugar social, dar-se conta de que fala a partir de determinado lugar social não é ter consciência do funcionamento enunciativo do qual faz parte; o funcionamento político e ideológico da linguagem sempre escapa, não é possível, por mais que queiramos, dominar os sentidos e ter controle sobre eles. Desse modo, quando o sujeito enuncia, sempre o fará a partir de uma inscrição em 1-x: "para o Locutor se representar como origem do que se enuncia, é preciso que ele não seja ele próprio, mas um lugar social de locutor" (GUIMARÃES, 2005, p. 24). Falar é se inscrever em uma posição enunciativa.

Da mesma forma que o L é agenciado na cena enunciativa pelo lugar social que ocupa, ou seja, por um (ou mais) l-x, o Alocutário (para/a quem se enuncia) é também agenciado por um al-x (ou mais), trazendo para o acontecimento da enunciação um lugar social que não é, necessariamente, um correspondente do l-x. O alocutário parece funcionar como uma projeção enunciativa criada pelo l-x que enuncia, projeta-se o lugar social que esse alocutário ocupa, sendo, portanto, decisivo o lugar político ocupado para o direcionamento argumentativo posto em movimento pelo locutor. No jogo enunciativo, o l-x constitui um al-x, afetados por uma temporalidade que não é a mesma de quem, fora da cena enunciativa, participa como leitor dos sentidos presentes na enunciação. A interpretação, nesse sentido, estaria em um al-y leitor. Assim, como ressalta Guimarães (2013a), a cena enunciativa é composta por um conjunto de figuras da enunciação que falam no acontecimento. 
O acontecimento para a teoria localiza-se na diferença, pois instala sua própria temporalidade. Ou seja, o acontecimento não é um fato no tempo, não é um acontecimento novo distinto de outros já ocorridos, mas temporaliza um presente e um futuro que funcionam ao significarem um passado: "esta latência de futuro, que, no acontecimento, projeta sentido, significa porque o acontecimento recorta um passado como memorável" (GUIMARÃES, 2013a, p. 12). Ressalta-se que essas enunciações anteriores que se materializam no enunciado não se referem a uma lembrança ou recordação pessoal de fatos ocorridos, mas a uma memória enunciativa na qual outras vozes ditas, repetidas, ressignificadas e apagadas pelo jogo político e histórico colado na língua emergem; é uma voz sem nome que vem à tona sem que o locutor se dê conta disso. Desse modo, a partir do memorável é possível estabelecer as redes de sentido presentes e observar sua constituição interdiscursiva.

Como dissemos, o interdiscurso - a memória discursiva sustenta o dizer em uma estratificação de formulações já feitas mas esquecidas e que vão construindo uma história de sentidos. É sobre essa memória, de que não detemos o controle, que nossos sentidos se constroem, dando-nos a impressão de sabermos do que estamos falando. (ORLANDI, 2001, p. 54 - grifos nossos).

Assim, o locutor, agenciado em determinada posição $\mathrm{x}$, desconhece o jogo político e histórico que intervém na língua, por isso a temporalidade da enunciação se apresenta como uma só, a dimensão do presente. O cruzamento do passado no presente que anunciam um devir é apagado no dizer, fornecendo a impressão da unilateralidade temporal:

O sujeito não fala no presente, no tempo, embora o locutor o represente assim, pois só é sujeito enquanto afetado pelo interdiscurso, memória de sentidos, estruturada pelo esquecimento, que faz a língua funcionar. Falar é estar nesta memória, portanto não é estar no tempo (dimensão empírica). (GUIMARÃES, 2005, p. 14 - grifos nossos).

Nesse sentido, o conceito de interdiscurso da Análise do Discurso torna-se importante para a Semântica do Acontecimento, visto que o sentido em um acontecimento é efeito da presença do interdiscurso. Assim, ser sujeito é movimentar o interdiscurso, é trazer à tona a memória dos sentidos e é, ao mesmo tempo, esquecer-se do agenciamento político-histórico que permeia o lugar ocupado: o Locutor se constitui em meio a esse esquecimento, no apagamento de ocupar um ou mais locutores-x quando enuncia. 
V. 9 (1)

$252-269$

jan-abr

2019

A enunciação é, portanto, um acontecimento que abre espaço para que a memória signifique, ressignificando o passado no presente, anunciando um devir dos sentidos; é o ponto em que os lugares ocupados pelo sujeito confrontam-se com a história, o político e o simbólico imbrincados na língua. Trata-se de compreender o funcionamento da língua sem se remeter a centralidade do sujeito, posta em cheque pela teoria. O aporte teórico pauta-se na materialidade histórica do real: é no acontecimento da enunciação que o sentido da linguagem deve se localizar. Perceber o modo como se dá o agenciamento do locutor na cena enunciativa, bem como compreender a posição enunciativa por ele ocupada ( $1-\mathrm{x})$, diz respeito aos efeitos de sentido produzidos nesse agenciamento e na tessitura da diretividade argumentativa. É esse o ponto de interesse na análise empreendida na sequência.

\section{Diretividade argumentativa pelo processo de reescrituração}

Como mencionado, os recortes que compõem o corpus de análise são fruto de entrevistas realizadas com prostitutas, em 2012, em uma boate ${ }^{2}$ localizada na cidade de Cascavel-PR. São as histórias de vida de Mônica, Ana Paula, Carol e Duda ${ }^{3}$ que integram o corpus de análise. As entrevistas foram realizadas em dias diferentes: no primeiro dia (01/08) apenas Mônica concordou em participar da pesquisa e, no segundo dia (06/08), as outras três aceitaram ceder seus depoimentos, sendo que a entrevista com Ana Paula e Carol ocorreu simultaneamente. Para este recorte analítico, interessa-me compreender o direcionamento argumentativo conduzido pelos locutores, visto que o corpus é constituído por Locutores diferentes, mas ao serem agenciados na cena enunciativa, os l-x se cruzam, na evidência dos lugares ocupados pelo político e na repetição de sentidos que vêm de outro lugar e que irrompem enquanto um memorável na temporalidade da cena.

Visto a extensão deste trabalho e a possibilidade de trabalhar apenas com algumas das sequências enunciativas ${ }^{4}$, empreende-se neste momento

\footnotetext{
$\overline{2}$ Em respeito às exigências éticas em pesquisa, o nome do local não é revelado. Em outra pesquisa pautada nessa mesma entrevista, mas sob o viés da Análise do Discurso de orientação francesa, a boate em questão foi renomeada como Porto das Sereias. FERRAÇA, Mirielly. Prostituição: vozes que ecoam, sereias que (en)cantam. 2013. 165 f. Dissertação (Mestrado em Linguagem e Sociedade) - Universidade Estadual do Oeste do Paraná, Cascavel, 2013.

${ }^{3}$ As próprias entrevistadas sugeriram os nomes fictícios utilizados neste trabalho.

${ }_{4}^{4}$ Compreendo sequências enunciativas como recortes realizados a partir do corpus de análise. As sequências são analisadas na relação que estabelecem com o corpus, em condições de produção dadas, e não isoladamente.
} 
uma breve descrição do que é o corpus e como o todo significa nas sequências selecionadas para esta análise. Apesar de serem histórias diferentes, alguns pontos entrelaçam-se: todas as entrevistadas são mães; possuem quase 30 anos; não moram na mesma cidade em que se encontra a boate; dizem aos filhos, familiares e amigos que exercem outra atividade empregatícia; estão sempre viajando para boates de cidades e Estados diferentes (Santa Catarina, Paraná, São Paulo, Mato Grosso do Sul); são divorciadas e, segundo o que relatam, desejam casar-se novamente, desejam deixar a prostituição e trabalhar em outra atividade. Histórias demasiadamente comuns se não reverberassem no mesmo a contradição e o conflito existente na história e no jogo político amarrados na(s) língua(s), o que possibilita perceber que a repetição revela muito mais do que o mero no mesmo. A repetição não está apenas nos pontos em comum das histórias narradas, mas, principalmente, e é isso que interessa, nos nós de um memorável sobre a prostituição, sobre a mulher e sobre a maternidade que irrompem na cena enunciativa.

Amemóriaestabilizada sobreaprostituição ecoa nas entrevistas. Lugar moralmente condenado (política-historicamente) para a mulher, a prostituição é negada pelos locutores. De outro lado, o discurso burguês (cristão) sobre a maternidade e a mulher de família irrompe na cena, significando esses lugares como ideais, corretos e aceitáveis para a mulher. Essa memória retorna no acontecimento enunciativo, por ser evocado na união das temporalidades presente, passado, futuro e pelo agenciamento do L em l-x (e, por conseguinte, toda a relação política e história que esses lugares ocupados e que deslizam suscita). A entrada para a prostituição, conforme relatado, localizar-se-ia: a) na falta de empregos que forneçam o que elas ganham com a prostituição; b) no divórcio; c) na influência de amigas; d) nos filhos; e) no próprio destino, mas não por prazer, por desejo, por vontade própria5.

A entrevista é fortemente marcada por um deslizar enunciativo, chamo a atenção para o direcionamento argumentativo do l-x:

(SE 01) Eu sempre digo assim, oh: Eu não sou puta, eu sou menina de família com problemas financeiros: SPC, Procon, Serasa. (Carol - grifos nossos).

\footnotetext{
5 Em pesquisa posterior (2017), realizada com a Associação de prostitutas de Campinas-SP, Mulheres Guerreiras, o discurso é outro: há muitas mulheres que não só defendem a escolha que fizeram ao tornarem-se prostitutas como também reivindicam a nomeação puta, defendida como forma de empoderamento. As integrantes da Associação dão continuidade à luta de Gabriela Leite pela legalização da profissão.
} 
v. 9 (1)

252-269

jan-abr

2019
(SE 02) Somos, pra muitos ali fora, somos garotas de programa, mas não é, somos garotas de família com problemas financeiros... que é um método, curto, rápido e preciso de ganhar dinheiro. (Duda - grifos nossos).

Para a constituição da cena enunciativa da entrevista em questão, era necessário que as entrevistadas falassem sobre como é ser garota de programa, visto ser esse o objetivo da pesquisa. Entretanto, chamo a atenção para o fato de o lugar de garota de programa ser redirecionado nessas sequências acima destacadas, o $1-x$ transita e desliza para um outro lugar enunciativo. Dizer-se prostituta, assumirse garota de programa é trazer para o acontecimento da cena enunciativa um memorável sobre a venda de sexo, sobre o que é ser mulher, sobre como deve ser uma mulher, sentidos determinados socialmente por enunciados que significam as mulheres e esses lugares previamente, pela história. Ocorre nessas duas sequências enunciativas destacadas uma reescrituração de quem elas são, o que suscita que outros sentidos irrompam. Parte constitutiva da produção de sentidos e fundamental para o direcionamento argumentativo, a reescrituração é definida por Guimarães (2005) como os procedimentos de anáfora, catáfora, repetição, substituição e elipse que fazem os sentidos deslizarem, transitarem pelo texto, constituindo e contribuindo para a textualidade. Não há texto sem processo de deriva de sentidos, diz o autor, sem reescrituração: "Esta deriva enunciativa incessante é que constitui, a um só tempo, os sentidos e o texto" (GUIMARÃES, 2005, p. 28 - grifos nossos).

A reescrituração é estruturante do texto. A deriva instaurada pela negação de ser "puta" (SE 01) ou "garota de programa" (SE 02) e a afirmação de ser "menina de família com problemas financeiros" (SE 01) e "garotas de família com problemas financeiros" (SE 02) conduz a textualidade para outro lugar. As palavras ou expressões reescritas funcionam na relação que estabelecem entre o que foi dito e o que foi reescrito. Assim, dizer que é "menina de família" ou "garota de família" só funciona na relação com o que é dito antes: "puta", "garota de programa". A reescrituração, defende Guimarães, só funciona em relação a um memorável:

E ao reescriturar, ao fazer interpretar algo como diferente de si, este procedimento atribui (predica) algo ao reescriturado. E o que ele atribui? Aquilo que a própria reescrituração recorta como passado, como memorável. (GUIMARÃES, 2005, p. 28). 
É o trabalho da memória que incide na reescrituração, assim o que foi reescriturado pelo locutor $(1-x)$ funciona a trazer à cena, no encontro das temporalidades, sentidos que significam antes a mulher de família.

A relação estabelecida entre o reescriturado e o que reescreve é transitiva, simétrica e não-reflexiva (GUIMARÃES, 2009, p. 53). É simétrica porque um elemento é reescriturado pelo outro e vice-versa, fazendo-os significar no texto e a partir do texto que integram. Ou seja, não se trata de uma mera substituição, os termos passam a significar na relação que estabelecem entre si, no texto. Não é reflexiva porque a reescrituração não estabelece uma igualdade, um termo não é igual ao outro, mesmo que a reescrituração ocorra por repetição (por exemplo, quando Paulo é reescriturado por Paulo). Para explicar a relação transitiva, Guimarães (2009, p. 53) cita como exemplo a elipse, funcionamento que ocorre à distância e transversalmente. Assim, na reescrituração estabelecida nas SE 01 e 02, a relação estabelecida entre a negação e a afirmação é simétrica, não-reflexiva, visto que os sentidos trabalham um em relação ao outro, mas não estabelecem igualdade ou mera substituição de sentido.

Apesar de serem prostitutas, elas negam essa nomeação e definem-se como "menina de família" e "garota de família" com problemas financeiros. Essa reescritura mobiliza outros lugares, visto que se dizer "menina de família" ou "garota de família" é evocar pelo interdiscurso uma memória sobre a família (idílica-cristã-burguesa) e sobre o ideal que se tem sobre a mulher pertencente a essa esfera normatizada (e normalizadora). Circunscreve nesse imaginário o comportamento ideal para uma mulher de família, inclusive colocase em jogo sentidos que significam a mulher e sua relação com o sexo (ou a relação que se esperaria ou se aceitaria que a mulher tivesse em relação ao sexo, ao seu sexo). A deriva conduz a textualidade e produz novos sentidos na própria diferença do que foi reescrito. Desse modo, defende Guimarães (2005, p. 28), é na e pela diferença que os sentidos se constituem: "Quando uma forma se dá como igual/correspondente a outra (a anaforiza, a substitui, etc), o sentido está se fazendo como diferença e constitui a textualidade". Entretanto, ressalta-se que o complemento "problemas financeiros" que comparece nas duas SEs ancora a necessidade de recorrer à prostituição e ao mesmo tempo reafirma o imaginário de que a prostituição só é exercida por necessidade, por falta de opção. Estão em jogo aqui dois movimentos argumentativos, 
V. 9 (1)

$252-269$

jan-abr

2019

um que as coloca nesse lugar idealizado para a mulher (de família), ou seja, elas se dizem pertencentes a esse lugar, e outro que justifica a entrada na prostituição, "problemas financeiros". O que de fato é marcado nesse direcionamento argumentativo é que elas não querem se prostituir, mas se o fazem, mesmo sendo "meninas de família", é pela falta de dinheiro.

No jogo político de afirmações de pertencimento, ao dizerem: "não sou uma puta, sou uma menina de família" ou uma "garota de família", elas trazem à tona um discurso moral sobre a prostituição, segundo o qual a puta/a garota de programa é alguém moralmente condenável, novamente numa inscrição na memória burguesa sobre família. Reivindicar o lugar de garota de família é afirmar que, diferentemente do que socialmente se pensa, elas têm moral. Parece haver a negação de um pertencimento a um certo tipo de prostituta (como aquela que se prostitui porque gosta, por exemplo), continuando a atribuir o julgamento social de moralidade a estas.

Na SE 01, o advérbio de tempo marca a frequência com que ela diz que não é puta: "Eu sempre digo", funcionando como uma constante negação de ser o que é, seja pela própria constituição da cena em que o al-x é uma mulher pesquisadora, seja pelo próprio irromper de um memorável sobre não poder exercer a venda de sexo sem que recaia um julgamento moral (social-histórico-político) sobre si. Aliado a isso tudo, está o direcionamento argumentativo dado por esse l-x que quer se colocar num outro lugar, aquele idealizado socialmente para a mulher: "garota de família", "menina de família". Mesmo havendo uma negação na ordem da língua, o lugar ocupado de prostituta não se apaga, visto que só é possível negar assumindo este lugar de dizer (de prostituta) a partir do qual elas são convocadas a falar.

A mesma negação comparece na SE 02 usada por um outro locutor, agenciado por um l-x garota de programa. A negação é marcada na sequência por um operador argumentativo que instaura como argumento mais forte aquilo que é contraposto ao primeiro, o "mas não é" nega que se trata de "garotas de programa" para dar maior intensidade ao fato de se tratar, pelo contrário, de "garotas de família". A própria utilização do "mas" nesse caso demonstra a adversidade que existe entre um lugar e outro, e estar do outro lado, naquele que é idealizado no jogo histórico-político, é o lugar que o locutor deseja intensificar, é esse o direcionamento dado. Desse modo, seguindo a linha analítica, poderíamos pensar em conclusões opostas a 
que conduzem os argumentos ligados pelo "mas": garota de programa $\rightarrow$ mulher sem moral / garota de família $\rightarrow$ mulher com moral, assim o operador argumentativo sinaliza a tensão que há na moralidade (ou na falta dela) entre os dois lugares e direciona o argumento que se quer significar pelo locutor.

Além desse lugar idealizado da mulher enquanto aquela pertencente à família, ligada aos preceitos tidos como corretos, o locutor desliza também para o lugar materno (SE 03 e 04). Destaco que esse direcionamento argumentativo se inscreve na história e no jogo político que constitui esses lugares socialmente, caso contrário não haveria problemas (morais-sociais) em se assumir nesse lugar da prostituição (e nos casos em que o locutor (l-x) se assume, a inscrição políticahistórica é outra e produz outros sentidos); assim o deslizamento se dá na e pela história, não por uma vontade individual.

A dualidade de lugares constituídos como opostos emergem novamente no conflito e no confronto posto pelo político na língua, sendo o político compreendido por Guimarães (2005) como a contradição de uma normatividade que se constitui desigualmente na divisão do real. A maternidade é um dos preceitos estabelecidos como normal e natural a uma mulher, sendo considerada, inclusive, sinônimo de completude. Mais do que se associar a maternidade a algo natural, em um sentido físico e genético, torna-se, por extensão, socialmente natural que a mulher (se case) tenha filhos, seja uma boa mãe. O que se quer dizer, é que há uma memória atrelada e amarrada à palavra mulher, e por extensão à palavra mãe, em que os sentidos irrompem na cena enunciativa sem pedir licença, que significa antes, sem que o locutor se dê conta. Assim, ao redor do lugar materno circunscrevem determinados sentidos estabilizados para a maternidade, significada como amor incondicional, aquela que faz sacrifícios pelo bem maior, que são os filhos, exemplo de dedicação e bondade. Esses efeitos de sentido emergem no acontecimento da cena enunciativa destacada, visto serem postos em movimento pela memória, o passado que se entrelaça no presente da enunciação, antecipando um futuro significativo dessa relação.

(SE 03) Minha filha tem 14 anos, né? E meu filho tem 12. E... é o meu foco, na verdade, né? Meu e de todas daqui. Assim, trabalho assim nessa vida pra dar o melhor pros meus filhos. (Duda - grifos nossos). 
V. 9 (1)

$252-269$

jan-abr

2019

(SE 04) Então, eles são alguma coisa pra pode alegra nós por dentro, pior nós seria se nós tivesse abandonado nossos filhos, tivesse jogado na rua, alguma coisa assim. Não. Nós tamo aqui por eles. Por eles que nós tamo aqui. Então, ninguém tem que fala nada. Só que é feio minha filha sabê, minha filha com 12 anos que eu tô na zona. (Carol - grifos nossos).

Nota-se nas sequências destacadas acima que o l-x materno irrompe na cena enunciativa, em tensão com o l-x garota de programa. Tanto na SE 03 como na SE 04, as entrevistadas transitam entre o lugar daquela que vende sexo para aquela que se sacrifica pelos filhos. Pelos enunciados, parece, inclusive, que o lugar $1-x$ garota de programa só é ocupado porque antes disso ela é agenciada no lugar l-x mãe: ser mãe é o argumento que justifica ser prostituta: "Assim, trabalho assim nessa vida pra dar o melhor pros meus filhos" e "Nós tamo aqui por eles. Por eles que nós tamo aqui". Apesar disso, em outros momentos ambas entrevistadas disseram ter começado a se prostituir muito novas, antes mesmo de serem mães. O que está em jogo no direcionamento argumentativo é mais uma vez a negação de ser uma prostituta (condenada moralmente e julgada socialmente), e a defesa de ser uma menina de família com problemas financeiros que faz tudo para manter/cuidar dos filhos. Desse modo, ser puta por necessidade, em nome do grande valor da moral social, a família, não as coloca no mesmo lugar que aquelas tidas como sem moral, aquelas que se prostituem porque querem/gostam.

Reitero a ilusão do controle dos sentidos tal como posta anteriormente pela teoria. O locutor manobra a linguagem a seu favor, mas não se dá conta dos sentidos outros que se inscrevem em seu dizer. O direcionamento argumentativo dá visibilidade a um funcionamento social que significa antes e inscreve determinados sentidos a esses lugares ocupados pelo locutor: mulher, prostituta, mãe, menina/garota de família. Ainda, embora tentem negar o lugar da prostituição na tentativa de deslizar para os lugares de menina/garota de família, não se apaga o lugar ocupado. Pela reescrição, esses lugares funcionam na relação que estabelecem entre si, pela contradição e pela diferença que se marca na cena enunciativa. O que ocorre nas SE destacadas é uma diretividade argumentativa necessária de L, considerando a cena enunciativa e seu AL (agenciado em al-x). Afinal, nessas condições (enunciativas, políticas e sociais) seria possível dizer que gosta de e sente desejo em estar na prostituição? 
Como já comentado anteriormente, a composição da cena enunciativa se dá em uma boate e o objetivo explicitado às entrevistadas é que se trata de uma pesquisa acadêmica sobre a prostituição, assim o locutor só poderia ser uma garota de programa sendo seu al-x um entrevistador. Sabe-se, como explicitado, que o locutor não possui controle sobre o $1-\mathrm{x}$ ou os vários $1-\mathrm{x}$ que podem aparecer durante a enunciação, entretanto, a posição l-x materna ora irrompe na cena como parte de uma orientação argumentativa para o alocutário, ora como o próprio lugar materno sobredeterminando o de garota de programa (como destacarei na sequência 05).

Não se trata, evidentemente, de persuasão ou de convencimento, mas da sustentação de uma posição a partir de um direcionamento argumentativo. O locutor dessa cena redireciona o lugar ocupado e esperado da garota de programa para o materno, sustentando em sua argumentação o quão boas mães elas são: (SE 03) os filhos são o foco e ela trabalha como garota de programa (única e exclusivamente, faz parecer) para dar o melhor aos filhos; (SE 04) pior (que ser garota de programa, a comparação parece ser essa) seria se elas tivessem abandonado ou jogado os filhos na rua, elas, no entanto, estão ali por eles. A posição materna ressaltada na entrevista direciona o foco enunciativo para esse lugar e, mais que isso, evidencia o quão boas mães elas são, funcionando como uma justificativa para o lugar de garota de programa ocupado. O lugar da prostituta é na linha enunciativa "apagado" e o foco se volta para a excelência do lugar materno desempenhado; entretanto, cabe ressaltar, o l-x garota de programa não é suprimido da enunciação, ele continua ali, significando o que é dito.

Assim, o acontecimento enunciativo cruza a memória que se tem sobre a prostituição e também, em contraponto, o já-dito sobre a maternidade, sobre a menina/garota de família; são essas outras vozes que emergem no presente enunciativo. Mesmo se tratando de uma entrevista em que o foco é a prostituição, na qual é solicitado que se fale sobre a prática exercida, pergunto novamente: o que significaria se assumir nesse lugar e afirmar gostar do que faz? Além do jogo inescapável do político e do histórico que interferem no que se diz e em como se diz em uma enunciação dada, o alocutário também interfere na diretividade argumentativa: a "defesa" instaurada relaciona-se com a cena enunciativa.

Assumir prostituir-se pelo bem maior que são os filhos, fato reiterado durante a entrevista, visa livrá-las do julgamento moral: (SE 
V. 9 (1)

$252-269$

jan-abr

2019

03) "Minha filha tem 14 anos, né? E meu filho tem 12. E... é o meu foco, na verdade, né? Meu e de todas daqui. Assim, trabalho assim nessa vida pra dar o melhor pros meus filhos", se os filhos são o foco da vida da entrevistada, assim/logo seria óbvio que ela se prostituiria para dar o melhor para eles, tão óbvio como qualquer mãe o faria. (SE 04) "Nós tamo aqui por eles. Por eles que nós tamo aqui. Então, ninguém tem que fala nada". Neste caso, a direção argumentativa seria: se faço o que faço pelos meus filhos, pelo outro (como se fosse um sacrifício), então ninguém deve me julgar por isso. Ou seja, se ela desempenha com esmero o papel de mãe, se esse é o propósito do que é ser mãe, então não se abre espaço para que a julguem por se prostituir. Há, na orientação argumentativa, uma sobreposição do lugar materno sobre o de prostituta, mas que para o al-y leitor essa sobreposição evidencia ainda mais a presença do $1-x$ garota de programa, lugar que se tenta apagar dando mais ênfase ao sacrifício materno.

Redirecionar o lugar de prostituta para o materno só é possível pela presença do interdiscurso no acontecimento. Há outras vozes ditas antes no jogo político que circunscrevem e definem o que é uma garota de programa e o que é ser mãe, que irrompem na cena enunciativa, como defende Guimarães (2010, p. 79):

A diretividade da enunciação, própria da orientação argumentativa, se sustenta no já-dito do interdiscurso que movimenta a língua. $O$ interdiscurso, o externo à língua nesta posição que adoto, é que movimenta a língua, que põe em funcionamento. É o interdiscurso que constitui o sentido da argumentação. Deste modo a língua tem uma autonomia relativa. Por esta razão é que se pode dizer que a língua é, também ela, histórica. (grifos nossos).

Se o interdiscurso constitui o sentido na argumentação, como assevera Guimarães (2010) na citação anterior, tem-se que só é necessário justificar o que fazem porque justamente existe uma memória acerca da prostituição condenando a prática. Um professor, numa situação de entrevista, por exemplo, não precisaria justificar o porquê de estar no lugar que ocupa e poderia, inclusive, afirmar que gosta do que faz ou porque é professor pelo retorno financeiro, sem que recaísse sobre si uma condenação moral. E, ainda, só se enaltece a maternidade porque também existe uma memória, que fala antes e que ao mesmo tempo constitui o dizer, que reafirma ser a maternidade o papel ideal da mulher, associando ainda a mãe (em contraponto com a puta) como santa, aquela que faz sacrifícios pelo filho. São lugares constituídos 
historicamente como opostos: "a sacralização do papel social da mãe passava, portanto, pela construção do seu avesso: a mulher mundana, lasciva e luxuriosa, para quem a procriação não era dever, mas prazer" (PRIORE, 1995, p. 83).

Apesar de buscar no papel de boa mãe uma justificativa, tal contraponto não é de todo eficaz, caso contrário, mesmo estando ancoradas em inúmeras justificativas plausíveis, não precisaria esconder dos filhos a prática exercida: "só que é feio minha filha sabê, minha filha com 12 anos que eu tô na zona". Ecoa com mais força o lugar da prostituição, nesse caso, o lugar de prostituta se sobrepõe ao materno. Há, portanto, nessas SE 03 e 04, um conflito e confronto de memórias distintas cruzando o acontecimento enunciativo. Elas se identificam com o discurso moral predominante segundo o qual é errado ser prostituta.

(SE 05) Pesquisador: E os filhos de vocês, os mais velhos sabem?

- (Carol) Não, tá louca?

- (Ana Paula) Nem pensá.

- (Carol) Deus o livre... Nunca. Por isso que eu tô saindo, minha filha tem doze anos. Deus o livre, ela não é loca. O que a gente passa por causa deles, imagine um dia ela querê fazê o mesmo que eu? Eu mato ela. (grifos nossos).

Os filhos não podem saber, pois, apesar de haver um "sacrifício" materno, os sentidos negativos sobre a prostituta irrompem com mais força; há uma clara divisão feita pela história que distingue esses dois lugares. Mesmo que seja justificado no fio enunciativo a entrada e a permanência na prostituição pelos filhos, a mesma justificativa (ou ainda outras) não serviria para os filhos, pois ao considerá-los ocupando o lugar da prostituição, tal como as mães ocupam, o que irrompe enunciativamente é o lugar materno, aquela que proíbe, enquanto boa mãe, os filhos de realizar práticas tidas como erradas, moralmente condenadas.

A composição da cena enunciativa evidenciada neste trabalho relaciona-se fortemente com a memória. Trata-se de um acontecimento afetado pela história, pelo cruzamento de dizeres diversos imersos no jogo político e nas condições sociais que os constituem. Não há enunciados que não se relacionem com outros: 
v. 9 (1)

252-269

jan-abr

2019 os sentidos resultam de relações: um discurso aponta para outros que o sustentam, assim como para dizeres futuros. [...] Um dizer tem relação com outros dizeres realizados, imaginados ou possíveis. (ORLANDI, 2001, p. 39).

É a partir de um memorável no acontecimento que os sentidos do direcionamento argumentativo se constituem, construindo um futuro na cena.

\section{Considerações finais}

O que está em jogo no direcionamento argumentativo não é o convencimento, não se trata de atribuir uma verdade ao que é dito pelo locutor, mas de dar evidência ao modo como o processo argumentativo ocorre, ao modo como o $1-\mathrm{x}$ produz sentidos ao al-x em um dado acontecimento. Ainda, também não se trata de saber se $\mathrm{o}$ al-x se convenceu do que é dito, defendido por aquele que enuncia. Trata-se de dar visibilidade a esse movimento realizado na e pela linguagem, considerando lugares sociais no imbricamento de temporalidades; trata-se de mostrar como o exterior (o histórico e o político) constituem os sentidos.

Agenciado na cena enunciativa, o locutor é tomado pela história em sua relação política, cruzando o passado no presente do acontecimento enunciativo. O lugar da maternidade e o da menina de família irromperam nas SE analisadas como diretividade argumentativa do locutor, tomado pela posição de garota de programa. Entretanto, mesmo sob a pretensa tentativa de apagar, redirecionar o lugar da prostituição, é esse lugar social que se mantém mesmo quando um certo sentido de prostituta é negado.

\section{Referências}

FERRAÇA, Mirielly. Prostituição: vozes que ecoam, sereias que (en)cantam. 2013. 165 f. Dissertação (Mestrado em Linguagem e Sociedade) - Universidade Estadual do Oeste do Paraná, Cascavel, 2013.

GUIMARÃES, E. R. J. Semântica do acontecimento: um estudo enunciativo da designação. Campinas, SP: Pontes, $2^{\mathrm{a}}$ edição, 2005.

A Enumeração: Funcionamento Enunciativo e Sentido. In. GUIMARÄES, Eduardo e ZOPPI-FONTANA, Mónica G. (orgs.). Caderno de Estudos Linguísticos. Universidade Estadual de Campinas. Instituto de Estudos da Linguagem - Campinas, SP, n. 1 (ago. 1978) Publicação Semestral. 2009. 
Os limites do sentido: um estudo histórico e enunciativo da linguagem. Campinas: Editora RG, 4. ed., 2010.

Argumentatividade e argumentação. Revista do Programa de PósGraduação em Letras da Universidade de Passo Fundo. V.9, n. 2, p. 271283,jul./dez., 2013 a.

Entre o novo e a moda. In:

Joelma Aparecida Brewssanin; Neuza Zattar; Taisir Mahmudo Karim; Ana Maria Di Renzo. (Org.). Linguagem e interpretação: a institucionalização dos dizeres na história. 1. ed. Campinas: RG Editora, 2013 b, p. 61-85.

ORLANDI, E. P. Análise de Discurso: princípios e procedimentos. Campinas, SP: Fontes, 3. ed., 2001.

PÊCHEUX, M. Semântica e discurso: uma crítica à afirmação do óbvio. 5. ed. Trad. Eni Puccinelli Orlandi. Campinas: Editora da Unicamp, 2014.

PRIORE, M. D. Ao sul do corpo: condição feminina, maternidade e mentalidades no Brasil Colônia. Rio de Janeiro: José Olympio, 1995. 